\title{
PRORAČUN ČELIČNIH TANKOSTIJENIH NOSAČA PREMA EN 1993-1-3
}

\author{
Davor Skejić \\ Sveučilište u Zagrebu, Građevinski fakultet, docent \\ Ranko Ćosić \\ Sveučilište u Zagrebu, Građevinski fakultet, student
}

Sažetak: Osnovni problem čeličnih tankostijenih nosača, lokalni instabilitet dijelova poprečnog presjeka koji se nalaze u tlaku, može se riješiti povoljnim profiliranjem (ukrućivanjem) poprečnog presjeka nosača. Optimizacijom rasporeda ukrućenja u poprečnom presjeku može se u potpunosti spriječiti lokalni instabilitet te time povećati otpornost nosača bez dodatnog utroška materijala. Veliki utjecaj na otpornost ovakvih nosača, osim ukrućenja, može imati i pridržanje pojasnice profiliranim limom. U članku su prikazani normirani postupci kojima se na brz i jednostavan način može proračunati utjecaj ukrućenja i utjecaj pridržanja pojasnice nosača pokrovnim limom. Konkretnim primjerom kvantificiran je utjecaj ukrućenja i pridržanja pojasnice $C$ podrožnice trapeznim limom. Naglašene su mogućnosti suvremene norme EN 1993-1-3, koje uz malo dodatnog projektantskog napora na jednostavan način omogućuju znatnu uštedu koja se može polučiti iz realnog razmatranja tankostijenih profila.

Ključne riječi: tankostijeni nosači; lokalni instabilitet; ukrućenja; pridržanje pojasnice nosača profiliranim limom; EN 1993-1-3; ušteda

\section{DESIGN OF THIN-WALLED STEEL MEMBERS ACCORDING TO EN 1993-1-3}

\begin{abstract}
The main problem for steel thin-walled members, the local instability of compressed parts of crosssection, can be resolved by profiling (stiffening) of cross-section. By optimizing cross-section stiffeners arrangement, local instability can be completely prevented, and therefore member's resistance can be increased without usage of an additional material. Beside stiffeners, the restraint of member's flange with profiled sheet can have high influence on the resistance of these members. This article presents standardised procedures which allow quick and simple calculation of the stiffeners influence and for the influence of member's flange restraint by sheet roof. The stiffeners influences and the restraint of $C$ purlin by trapezoidal steel sheet are quantified on concrete example. In particular, the possibilities of modern standard EN 1993-1-3 are emphasized, which can, with a little extra designer work, provide significant savings from realistic consideration of thin-walled members.
\end{abstract}

Key words: thin-walled members; local instability; stiffeners; restraint of member flange with profiled sheet; EN 1993-1-3; savings 


\section{Uvod}

U ovome radu prikazane su osnovne smjernice za proračun tankostijenih nosača prema normi EN 1993-1-3. Tankostijeni nosači izrađeni su od hladno oblikovanih ravnih limova. Normom EN 1993-1-3 preporučena je debljina limova tankostijenih nosača: $0,45 \mathrm{~mm} \leq \mathrm{t} \leq 15 \mathrm{~mm}$ [1]. Smije se upotrijebiti i deblji i tanji materijal, uz uvjet da je otpornost određena proračunom utemeljenim na ispitivanju.

Najvažnija prednost tankostijenih nosača je povoljan odnos između njihove otpornosti i vlastite težine. $U$ usporedbi s upotrebom valjanih profila, ekonomska isplativost tankostijenih profila se očituje i u činjenici da je cijena limova po težini značajno manja od odgovarajućih valjanih I ili H profila. Ostale prednosti koje proizlaze iz male težine su: lagana izrada, nezahtjevan transport, lagana i brza montaža, manji temelji [2]. Tankostijeni nosači „pate“ od instabiliteta poprečnog presjeka i to čini njihovo ponašanje znatno kompleksnijim nego što je slučaj kod klasičnih presjeka korištenih u čeličnim konstrukcijama. Nakon dostizanja određenog intenziteta djelovanja, ne sudjeluje više čitav presjek u preuzimanju tog djelovanja. Neki dijelovi izmiču funkciji nošenja većim ili manjim izbočivanjem tankog lima u zoni pritiska [3].

$\mathrm{Na}$ otpornost takvih tankostijenih elemenata veliki utjecaj ima oblikovanje u smislu učinkovite profilacije. Proizvodni procesi su se značajno razvili te je lako dobiti različite profilacije i oblike čeličnog lima. Previjanjem rubova pojasnica, te izvođenjem profilacija na hrptu, može se spriječiti lokalni instabilitet i time povećati otpornost bez dodatnog utroška materijala. Te profilacije predstavljaju ojačanja poprečnog presjeka i nazivaju se ukrućenjima (previjanje rubova pojasnice - rubno ukrućenje, profilacija na hrptu - međuukrućenje).

$\mathrm{Na}$ otpornost tankostijenih nosača, osim ukrućenja, veliki utjecaj ima i pridržanje gornje pojasnice pokrovnim limom. Taj utjecaj proizlazi iz činjenice da tankostijeni nosači obično imaju malu torzijsku krutost, za razliku od valjanih profila koji imaju veću krutost te je zanemariv utjecaj bočnog pridržanja limom.

Provedena su i analizirana opsežna laboratorijska ispitivanja da se izrade postojeće europske norme za dimenzioniranje tankostijenih profila. U njima su dane brojne formule koje se dijelom temelje na teoriji, a dijelom na rezultatima laboratorijskih ispitivanja [4]. U nastavku su prikazani normirani postupci za proračun tankostijenih nosača prema euronormi. Na kraju rada je kroz jedan konkretni primjer proračuna tankostijenog nosača ukazano na mogućnosti suvremenih normi i znatnu uštedu koja se može polučiti uz malo dodatnog projektantskog napora.

\section{Normirani postupci za proračun tankostijenih nosača}

\subsection{Nosač bez ukrućenja i bez pridržanja}

\subsubsection{0pćenito}

Kako bismo što zornije prikazali neke specifičnosti tankostijenih nosača, najprije ćemo prikazati postupak proračuna tankostijenog nosača bez ukrućenja i bez bočnog pridržanja. Nosači bez ukrućenja imaju jednostavan poprečni presjek, tj. presjek kojeg čine ravni elementi bez izvedenih profilacija koje bi predstavljale ukrućenja (ojačanja) poprečnog presjeka.

\subsubsection{Geometrijski odnosi}

U normi [1] dana su geometrijska ograničenja koja je potrebno ispuniti da bi se norma uopće mogla primijeniti (tablica 1). 
Tablica 1 - Najveći omjeri širina - debljina

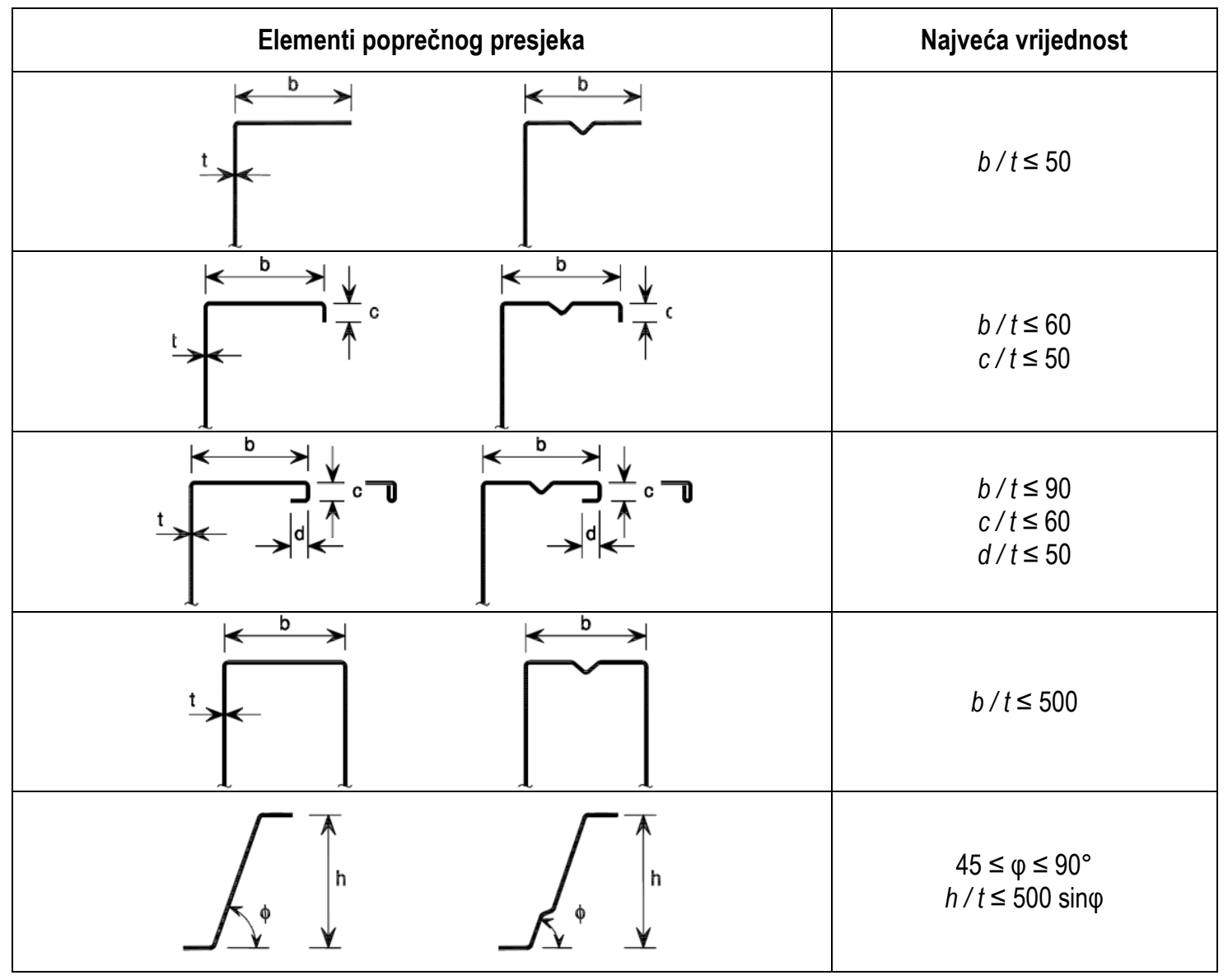

\subsubsection{Utjecaj zaobljenja uglova}

Poprečni presjeci tankostijenih nosača u biti sadrže određen broj ravninskih elemenata spojenih zakrivljenim elementima. Kod tankostijenih nosača potrebno je uzeti u obzir utjecaj zaobljenja uglova, te je potrebno odrediti fiktivne širine ravninskih elemenata poprečnog presjeka. Na poprečnom presjeku sa zaobljenim uglovima, fiktivna širina $b_{p}$ mjeri se od središnje točke zaobljenog ugla (slika 1).

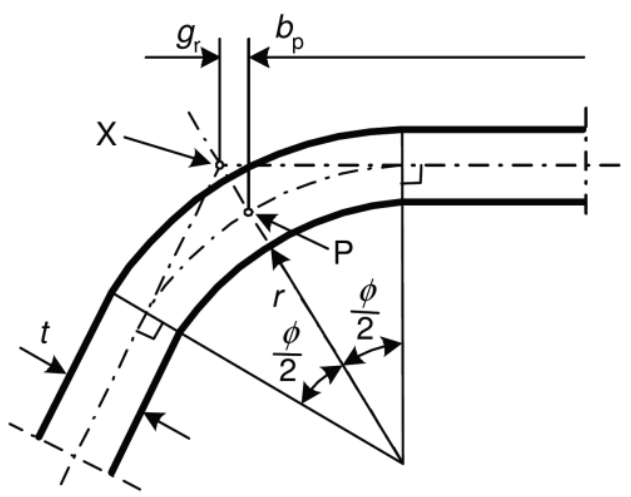

$$
\begin{aligned}
& X \text { - presjecište osi (hrpta i pojasnice) } \\
& P \text { - središte ugla } \\
& r_{m}=r+t / 2 \\
& \theta_{y}=r_{m}\left(\tan \left(\frac{\phi}{2}\right)-\sin \left(\frac{\phi}{2}\right)\right)
\end{aligned}
$$

Slika 1 - Fiktivne širine dijelova poprečnog presjeka $b_{p}$ kojima se u obzir uzimaju polumjeri uglova 
Zaobljenja uglova uvijek trebaju biti uzeta u obzir kod izračuna krutosti poprečnog presjeka. Kod proračuna otpornosti poprečnog presjeka, utjecaj zaobljenja uglova može se zanemariti ako je unutarnji polumjer $r \leq 5 \cdot t$ i $r \leq$ $0,10 \cdot b_{p}$, a poprečni presjek smije se pretpostaviti sastavljen od ravninskih elemenata s oštrim uglovima. $S$ druge strane, ako je unutarnji polumjer $r>0,04 \mathrm{tE} / \mathrm{f}_{\mathrm{y}}$ tada otpornost poprečnog presjeka treba odrediti ispitivanjima. $U$ normi [1] su dani aproksimacijski izrazi kojima se uzima u obzir utjecaj zaobljenja uglova reduciranjem geometrijskih svojstava izračunatih na idealiziranom poprečnom presjeku s oštrim rubovima. Utjecaj zaobljenja uglova moguće je uzeti u obzir i na stvarnoj geometriji poprečnog presjeka, tj. realan poprečni presjek sa zaobljenim uglovima (npr. pomoću modula Section Wizard [5], u programskom paketu STAAD.Pro 2007 [6]).

\subsubsection{Djelotvorni poprečni presjek}

S obzirom da se radi o vrlo tankim elementima, potrebno je posebnu pozornost obratiti lokalnom izbočivanju, jer ono uvelike utječe na otpornost i krutost nosača. Pri lokalnom izbočivanju elementa dolazi do neravnomjerne raspodjele napona, kako je prikazano na slici 2a). Bilo bi nepraktično proračunavati s takvom raspodjelom napona, te je stoga uveden koncept djelotvorne širine kojim dobijemo djelotvornu širinu za ravnomjernu raspodjelu napona (slika $2 b)$.

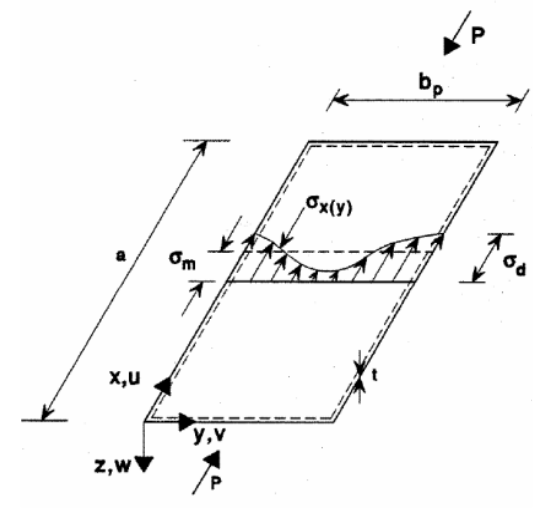

a)

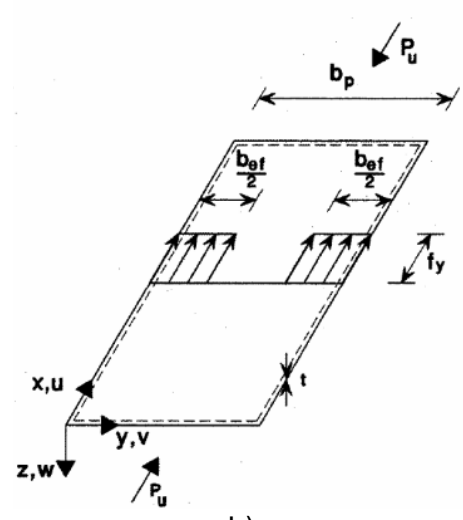

b)

\section{Slika 2 - Raspodjela napona u tankoj slobodno oslonjenoj ploči}

Djelotvorne širine neukrućenih elemenata određuju se prema normi EN 1993-1-5 [7] upotrebom fiktivne širine $b_{p} z a \bar{b}$, te određivanjem faktora redukcije za izbočivanje ploče utemeljenom na vitkosti ploče $\bar{\lambda}_{p}[1]$.

\subsection{Nosač sa ukrućenjima i bez pridržanja}

\subsubsection{0pćenito}

Kao što je već navedeno, ukrućenja su uzdužne profilacije elemenata poprečnog presjeka nosača kojima se sprječava lokani instabilitet elemenata. Međutim, sada se javlja drugi problem, a to je mogućnost izvijanja samog ukrućenja, tj. njegovog distorzijskog izvijanja.

\subsubsection{Geometrijski odnosi}

Osim geometrijskih odnosa danih u tablici 1 , kod nosača s ukrućenjima potrebno je ispuniti uvjete dodatnih ograničenja (oznake $b, c$ i $d$ prikazane su u tablici 1 ):

$$
0,2 \leq \mathrm{c} / \mathrm{b} \leq 0,6
$$




\section{$0,1 \leq \mathrm{d} / \mathrm{b} \leq 0,3$}

Ako je $c / b<0,2 \mathrm{ili} \mathrm{d} / \mathrm{b}<0,1$ previjeni rub lima se zanemaruje $(c=0, d=0)$.

Ove uvjete potrebno je ispuniti da bi se osigurala dovoljna krutost i izbjeglo primarno izvijanje samog ukrućenja. Nadalje, potrebno je provjeriti i utjecaj zaobljenja uglova kao što je prikazano u točki 2.1.3.

\subsubsection{Pojednostavljena metoda proračuna}

Učinke distorzijskog izvijanja treba odrediti provedbom linearnog ili nelinearnog proračuna izvijanja uporabom numeričkih metoda ili ispitivanja kratkog stupa, [1]. U euronormi je dana pojednostavljena metoda proračuna koja se može primijeniti samo za tankostijene nosače C ili Z profila [1].

\section{1. korak}

Proračun tlačnih elemenata s ukrućenjima temelji se na pretpostavci da se ukrućenje ponaša kao tlačni element $s$ djelomičnim kontinuiranim pridržanjem. Ovo pridržanje može se razmatrati kao opruga s krutošću, $K$, koja ovisi o rubnim uvjetima te o krutosti na savijanje susjednih elemenata [1]. U prvom koraku pretpostavlja se da ukrućenje daje punu upetost $(K=\infty)$ i da tlačno naprezanje u težištu ukrućenja iznosi $\sigma_{c o m, E d}=f_{y b} / \gamma_{M O}$, te se konceptom djelotvorne širine odredi početni djelotvorni poprečni presjek, slika 3. i 4.

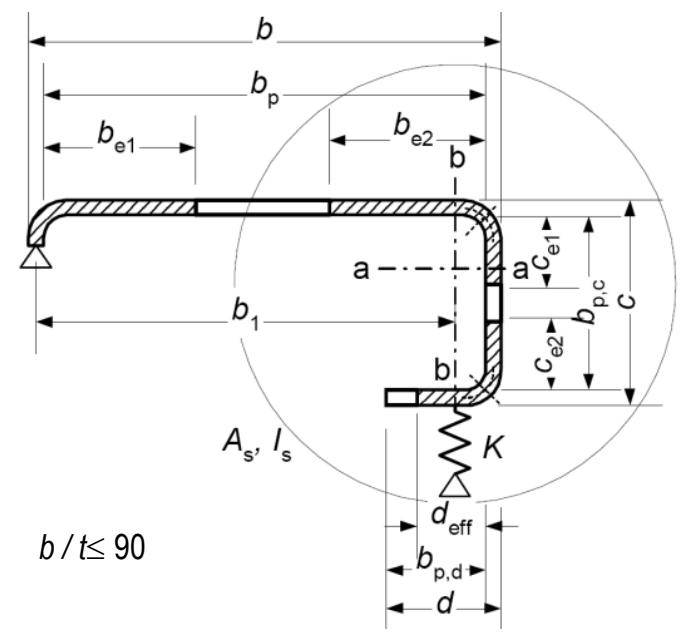

Slika 3 - Rubno ukrućenje

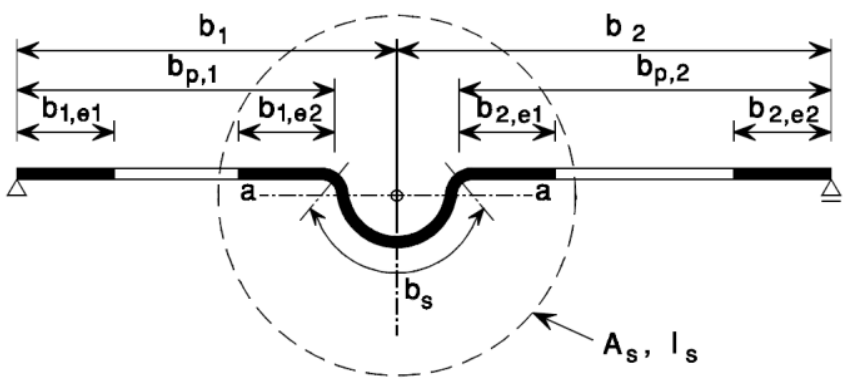

Slika 4 - Međuukrućenje

\section{2. korak}

Za poprečni presjek ukrućenja potrebno je uzeti dio koji tvori stvarni dio ukrućenja uvećan za djelotvorne dijelove susjednih ravninskih elemenata, slika 3. i 4. Potrebno je izračunati i moment tromosti ukrućenja $\left(I_{s}\right)$ za savijanje oko osi a-a. Nakon što smo dobili geometrijska svojstva ukrućenja $\left(A_{s} i I_{s}\right)$, možemo provjeriti mogućnost izvijanja samog ukrućenja, tj. distorzijskog izvijanja tog dijela presjeka, tako da odredimo krutost opruge ukrućenja $(K)$. Krutost opruge ukrućenja treba odrediti primjenom opterećenja $u$ po jedinici duljine (slika 5).

Krutost opruge $K$ po jedinici duljine može se odrediti iz izraza:

$$
K=u / \delta
$$

gdje je $\delta$ - progib ukrućenja zbog jediničnog opterećenja $u$ koje djeluje u težištu $\left(b_{1}\right)$ djelotvornog poprečnog presjeka. 


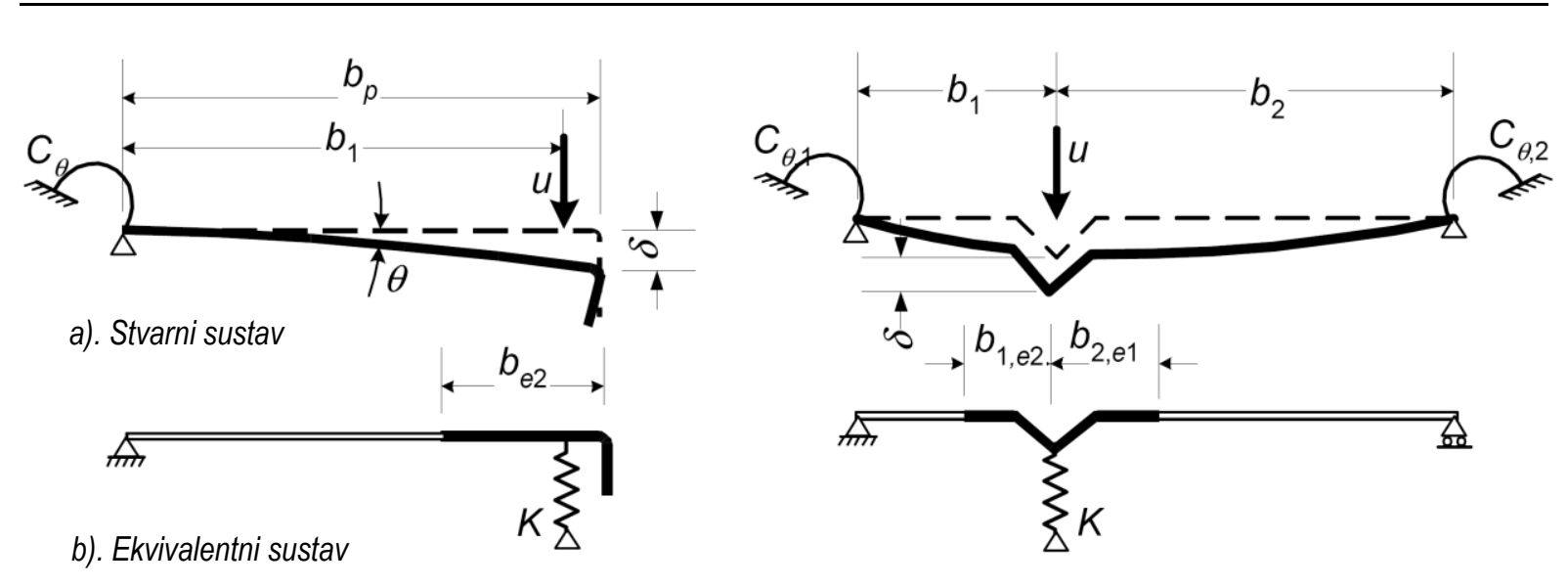

Slika 5 - Određivanje krutosti opruge

Za rubno ukrućenje, progib $\delta$ treba odrediti iz izraza [1]:

gdje je:

$$
\delta=\theta \cdot b_{p}+u \cdot \frac{b_{p}^{\mathrm{a}}}{3}, \frac{12\left(1-v^{2}\right)}{E t^{\mathrm{g}}} \quad \text { sa } \quad \theta=\frac{u \cdot b_{p}}{C_{\theta}}
$$

$b_{p}$ - fiktivna ravna širina ravninskih elemenata poprečnog presjeka (slike 3 i 4)

$C_{\theta}-$ krutost rotacijske opruge koja se određuje za jedinično opterećenje $u$ (slika 5)

Za međuukrućenje, kao konzervativna mogućnost mogu se krutosti rotacijskih opruga $C_{\theta 1} \mathrm{i} C_{\theta 2} z a n e m a r i t i\left(C_{\theta 1}=\right.$ $\mathrm{C}_{\theta 2}=0$ ), a progib $\delta$ se onda odredi iz izraza:

$$
\delta=\frac{u \cdot b_{1}^{2} \cdot b_{2}^{2}}{3\left(b_{1}+b_{2}\right)} \cdot \frac{12\left(1-v^{2}\right)}{E t^{3}}
$$

gdje je:

$b_{i}-$ udaljenost od spoja hrpta s pojasnicom do težišta djelotvorne površine ukrućenja (slika 5).

Što se tiče međuukrućenja, važno je napomenuti da je ova pojednostavljena metoda primjenjiva za elemente poprečnog presjeka s maksimalno dva međuukrućenja.

\section{3. korak}

U trećem koraku izračuna se elastični kritični napon $\sigma_{c r, s}$ za početni djelotvorni poprečni presjek $A_{s}$. Elastični

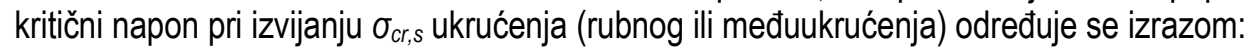

$$
\sigma_{\mathrm{crs} s}=\frac{2 \sqrt{K E I_{s}}}{A_{g}}
$$

\section{4. korak}

Faktor smanjenja $\chi_{d}$ otpornosti na distorzijsko izvijanje (izvijanje ukrućenja uz savijanje) treba odrediti iz relativne vitkosti $\overline{\bar{\lambda}}_{\bar{\omega}}$, iz izraza:

$$
\begin{array}{ll}
\chi_{\mathbb{d}}=1 & \text { ako je } \bar{\lambda}_{\mathbb{d}} \leq 0,65 \\
\chi_{\mathbb{d}}=1,47-0,723 \bar{\lambda}_{\mathbb{d}} & \text { ako jeo,65 }<\bar{\lambda}_{\mathbb{d}}<1,38 \\
\chi_{\mathbb{d}}=0,66 / \bar{\lambda}_{\mathbb{d}} & \text { ako je } \bar{\lambda}_{\mathbb{d}} \geq 1,38
\end{array}
$$

gdje je: 


\section{5. korak}

$$
\bar{\lambda}_{d}=\sqrt{f_{g} / \sigma_{E Y g}}
$$

Prethodne korake u nekim slučajevima je potrebno ponavljati radi točnijeg određivanja faktora smanjena za

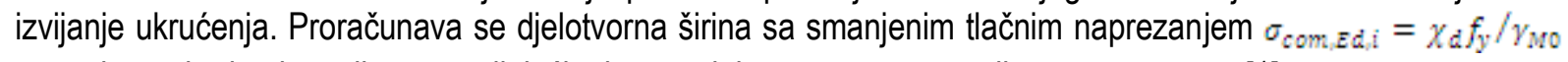

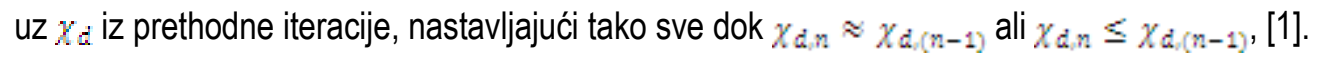

\section{6. korak}

Reduciranu djelotvornu površinu ukrućenja $A_{s, \text { red }}$ kojom se uzima u obzir distorzijsko izvijanje (izvijanje ukrućenja uz savijanje), treba odrediti iz izraza:

gdje je:

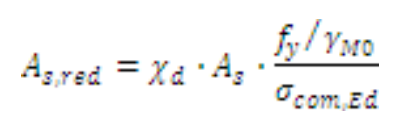

$\sigma_{\mathrm{com}, \mathrm{E}}$ - tlačno naprezanje na težište ukrućenja proračunatog s djelotvornim poprečnim presjekom.

Reducirana djelotvorna površina ukrućenja predočava se uporabom reducirane debljine tred $_{\text {vad }}$ za sve elemente uključene u $A_{g}$ :

$$
t_{\text {yed }}=t A_{\text {gyed }} / A_{g}
$$

Naposljetku, dobiven je reducirani djelotvorni poprečni presjek kojim je obuhvaćeno lokalno i distorzijsko izvijanje, te s tim presjekom određujemo otpornosti tankostijenog nosača s ukrućenjima.

\subsection{Nosač sa ukrućenjima i prodržanom gornjom pojasnicom}

\subsubsection{0pćenito}

U normi EN 1993-1-3, [1], jedno cijelo poglavlje (10) posvećeno je tankostijenim nosačima pridržanim trapeznim limom, te će se u ovoj točki obrazložiti koraci za proračun tankostijenog nosača s ukrućenjima kojemu je pridržana gornja pojasnica.

\subsubsection{Uvjet za bočnu upetost}

Norma daje uvjet koji je potrebno ispuniti da se gornja pojasnica na spoju s trapeznim limom može smatrati bočno upeta u ravnini lima:

$$
S \geq\left(E I_{\mathrm{w}} \frac{\pi^{2}}{\mathbb{L}^{2}}+G I_{\mathrm{t}}+E I_{\mathrm{z}} \frac{\pi^{2}}{L^{2}} 0,25 h^{2}\right) \frac{70}{h^{2}}
$$

gdje je:
S- dio posmične krutosti koji nastaje zbog lima, za razmatrani element spojen s limom na svakom rebru (ako je lim spojen s nosačem na svakom drugom rebru, tada $S$ treba zamijeniti s $0,20 S$ )
$I_{\text {W- }}$ konstanta vitoperenja nosača
$I_{\mathrm{t}^{-}}$torzijska konstanta nosača
L- raspon nosača
h- visina nosača.

Posmična krutost trapeznog lima povezanog s nosačem u svakom rebru i sa svake strane preklopa može se proračunati iz izraza [1]: 


$$
s=1000 \sqrt{t^{3}}\left(50+10 \cdot \sqrt[3]{b_{y o o f}}\right) \frac{s}{h_{h y}} \quad[N], t \text { i } b_{\text {roof }} \mathrm{u}[\mathrm{mm}]
$$

gdje je $t$ proračunska debljina lima, $b_{\text {roof }}$ širina krova, $s$ razmak nosača i $h_{w}$ je visina profila lima.

\subsubsection{Naprezanje uzrokovano torzijskim i bočnim savijanjem}

Otkazivanje zbog bočno-torzijskog izvijanja naročito je izraženo kod nosača čiji su poprečni presjeci izloženi torziji zbog nagiba glavnih osi s obzirom na smjer opterećivanja (Z profili), ili ako centar posmika presjeka nije u osi opterećenja (C profil) [3]. Ako takvome nosaču bočno upnemo gornju pojasnicu, presjek je i dalje izložen torziji, ali je spriječen u bočnom pomicanju pa će spoj između pokrova i podrožnice uzrokovati torzijsko i bočno savijanje presjeka. Ova pojava će utjecati na razdiobu normalnih naprezanja u poprečnom presjeku, a najveći će se utjecaj pojaviti u slobodnoj (donjoj) pojasnici.

Model tankostijenog nosača bočno pridržanog trapeznim limom prikazan je na slici 6 , gdje $C_{D}$ predstavlja rotacijsku upetost zbog pokrova od trapeznog lima.

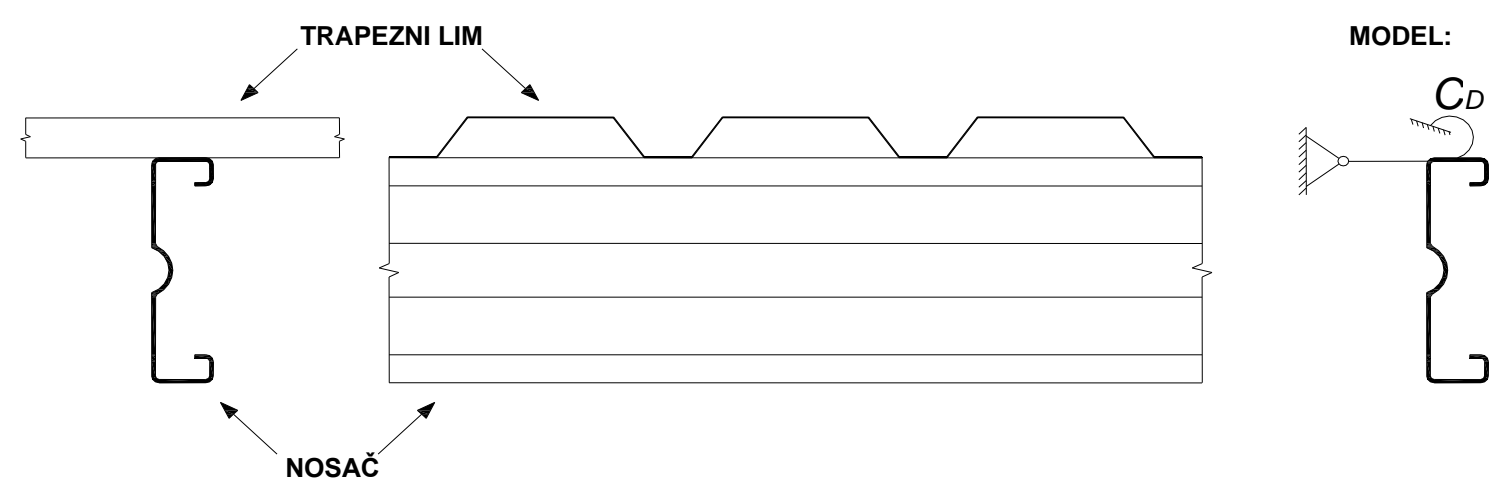

Slika 6 - Model nosača pridržanog trapeznim limom

Norma daje pojednostavljenu metodu proračuna u kojoj se rotacijska opruga $C_{D}$ zamjenjuje istovrijednom bočnom oprugom $K$. Slobodna pojasnica nosača modelira se kao nosač na elastičnoj podlozi krutosti $K$ i s poprečnim presjekom sastavljenim od slobodnog pojasa i dijela visine hrpta ( $1 / 5$ visine hrpta za C i Z presjek, te $1 / 6$ visine hrpta za $\Sigma$ presjek) [8]. Na taj način uzima se obzir težnja slobodne pojasnice da se pomiče bočno (što uključuje dodatna naprezanja), te se nosač proračunava kao da je opterećen bočnim opterećenjem $q_{h, E d}$, slika 7 .
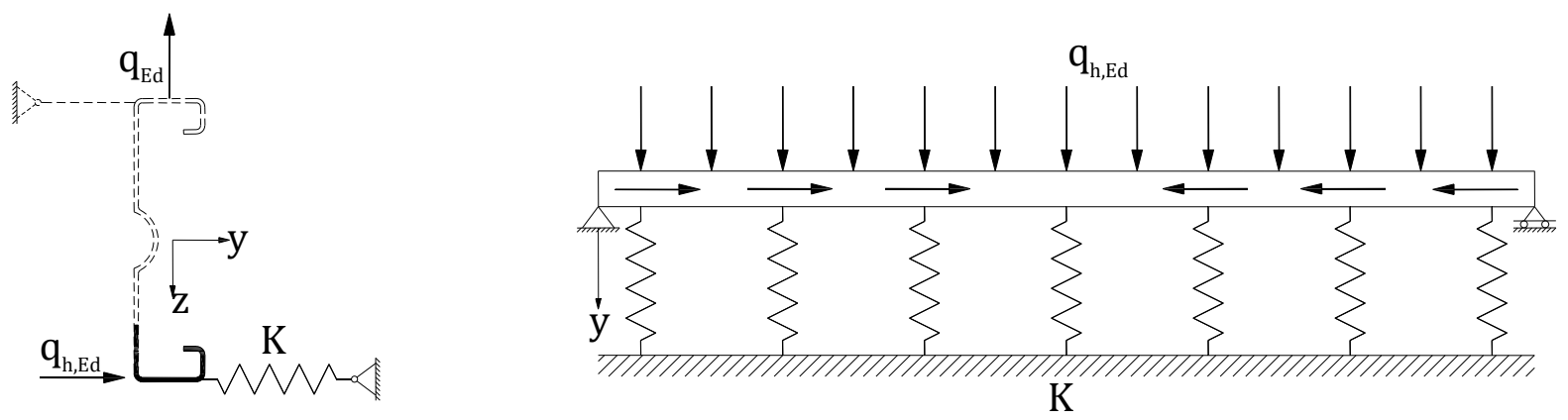

Slika 7 - Slobodna pojasnica nosača modelirana kao greda na elastičnoj podlozi

Dakle, elastična podloga je zamjenski model kojim se uzima u obzir deformacija na spoju podrožnice i pokrova, pojava poprečnog savijanja presjeka (distorzija) i savijanje pokrova. 


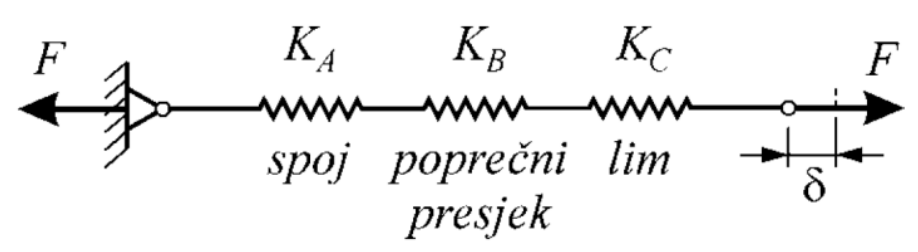

Slika 8 - Model bočne linijske opruge

Krutost zamjenske opruge, $K$, određuje se iz izraza, slika 8:

$$
\frac{1}{K}=\frac{1}{K_{A}}+\frac{1}{K_{B}}+\frac{1}{K_{G}}
$$

gdje je:

$K_{A^{-}} \quad$ bočna krutost koja odgovara rotacijskoj krutosti spoja podrožnice i pokrova

$K_{B}$ - bočna krutost poradi distorzije poprečnog presjeka podrožnice

$K_{\mathrm{C}^{-}} \quad$ bočna krutost poradi krutosti na savijanje pokrova (velika u odnosu na $K_{\mathrm{A}}$ i $K_{\mathrm{B}}$, pa se vrijednost $\mathbb{1} / K_{\mathrm{C}}$ obično zanemaruje).

Krutost bočne opruge $K$ po jedinici duljine može se odrediti upotrebljavajući izraz [1]:

$$
\frac{1}{K}=\frac{1}{K_{A}}+\frac{1}{K_{B}}=\frac{4\left(1-v^{2}\right) \cdot h^{2} \cdot\left(h_{d}+b_{\bmod }\right)}{E \cdot t^{1}}+\frac{h^{2}}{C_{D}}
$$

u kojemu je $b_{\text {mod }}$ određena kako slijedi:

- u slučaju gdje ekvivalentno lateralno opterećenje qhad zarotira podrožnicu tako da ona pritišće pokrov u točki gdje se spajaju hrbat i pojasnica, $b_{\text {mod }}=a$

gdje je:

- u slučaju gdje ekvivalentno lateralno opterećenje $q_{\mathfrak{R} B d}$ zarotira podrožnicu tako da ona pritišće pokrov u rubnoj točki pojasnice, $b_{\text {mod }}=2 \cdot a+b$

$t$ - debljina podrožnice

a - razmak od spoja lim-nosač do hrpta nosača

$b$ - širina pojasnice nosača spojene s limom

$C_{D}$ - krutost rotacijske opruge (prema točki 10.1.5.2 u EN 1993-1-3 [1])

$h$ - ukupna visina nosača

$h_{d}$ - razvijena visina hrpta nosača.

Pretpostavlja se da između ekvivalentnog bočnog opterećenja $q_{h, E d}$ i osnovnog (gravitacijskog, odnosno odižućeg) opterećenja $q_{E d}$ postoji konstantan odnos koji se izražava koeficijentom $k_{h}$, [8]:

$$
q_{\mathrm{R}, E d}=k_{\mathrm{R}} \cdot q_{E d}
$$

Koeficijent $k_{h}$ određuje se ovisno o obliku poprečnog presjeka nosača, te ovisno o tome radi li se 0 gravitacijskom ili odižućem djelovanju, što je detaljnije opisano u samoj normi EN 1993-1-3 [1].

\subsubsection{Moment savijanja oko slabije osi}

Moment savijanja oko slabije osi (bočni moment savijanja) $M_{f_{z z}, \mathbb{E}}$ može se odrediti izrazom:

gdje je:

$$
M_{f z_{2}, E d}=K_{R} \cdot M_{Q_{0}, f z_{1}, E d}
$$

$M_{Q_{0} f z_{\text {EA }}} \quad$ - početni bočni moment savijanja slobodne pojasnice bez oslonaca s oprugom 
$\kappa_{R} \quad$ - $\quad$ korekcijski faktor za djelotvorni oslonac s oprugom.

Navedeni se izraz ne može primijeniti za nosač kojemu se slobodna pojasnica nalazi u vlaku, zbog pozitivnog utjecaja kovrčanja pojasa (flange curling) i utjecaja drugog reda. U tom slučaju može se uzeti da je: $M_{f_{2} E d^{\circ}}=0$.

Korekcijski faktor $\kappa_{R}$ za odgovarajuće mjesto i rubne uvjete smije se odrediti prema tablici 2 (ili upotrebljujući teoriju nosača na elastičnoj Winklerovoj podlozi), upotrebljujući vrijednost koeficijenta $R$ od oslonca s oprugom danog izrazom:

gdje je:

$$
R=\frac{K \cdot L_{a}^{4}}{\pi^{4} \cdot E I_{f z}}
$$

$I_{f z}$ - moment tromosti bruto poprečnog presjeka slobodne pojasnice plus doprinos dijela hrpta za savijanje oko osi z-z (vidi sliku 7)

$L_{a}$ - razmak između ruku za smanjenje progiba ili, ako ih nema, raspon nosača $L$.

Tablica 2 - Vrijednost početnog momenta $M_{0, f z E d}$ i korekcijskog faktora $\kappa_{R}$

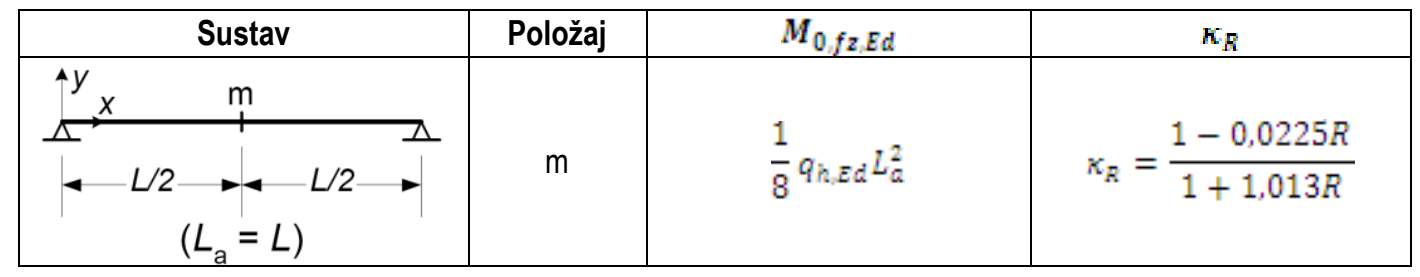

U tablici 2 je prikazan slučaj za jedan sustav i jedan položaj, dok su u normi [1] navedeni još neki slučajevi.

\subsubsection{Otpornost tankostijenog nosača s pridržanom gornjom pojasnicom}

Za tankostijene nosače opterećene uzdužnom silom i poprečnim opterećenjem, otpornost poprečnog presjeka treba provjeriti kao što je prikazano na slici 9, superpozicijom učinaka djelovanja zbog [1]:

- savijanja u svojoj ravnini $M_{y, E d}$

- uzdužne sile $N_{E d}$

- istovrijednog bočnog opterećenja $q_{h, E d}$ koje djeluje na slobodnu pojasnicu zbog torzije i bočnog savijanja.

Najveća naprezanja u poprečnom presjeku trebaju zadovoljiti izraze:

- za pridržanu (gornju) pojasnicu:

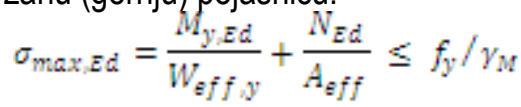

- za slobodnu (donju) pojasnicu:

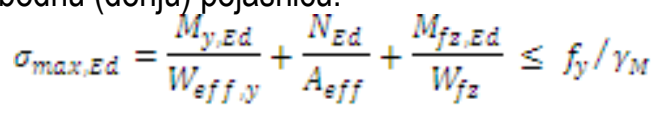




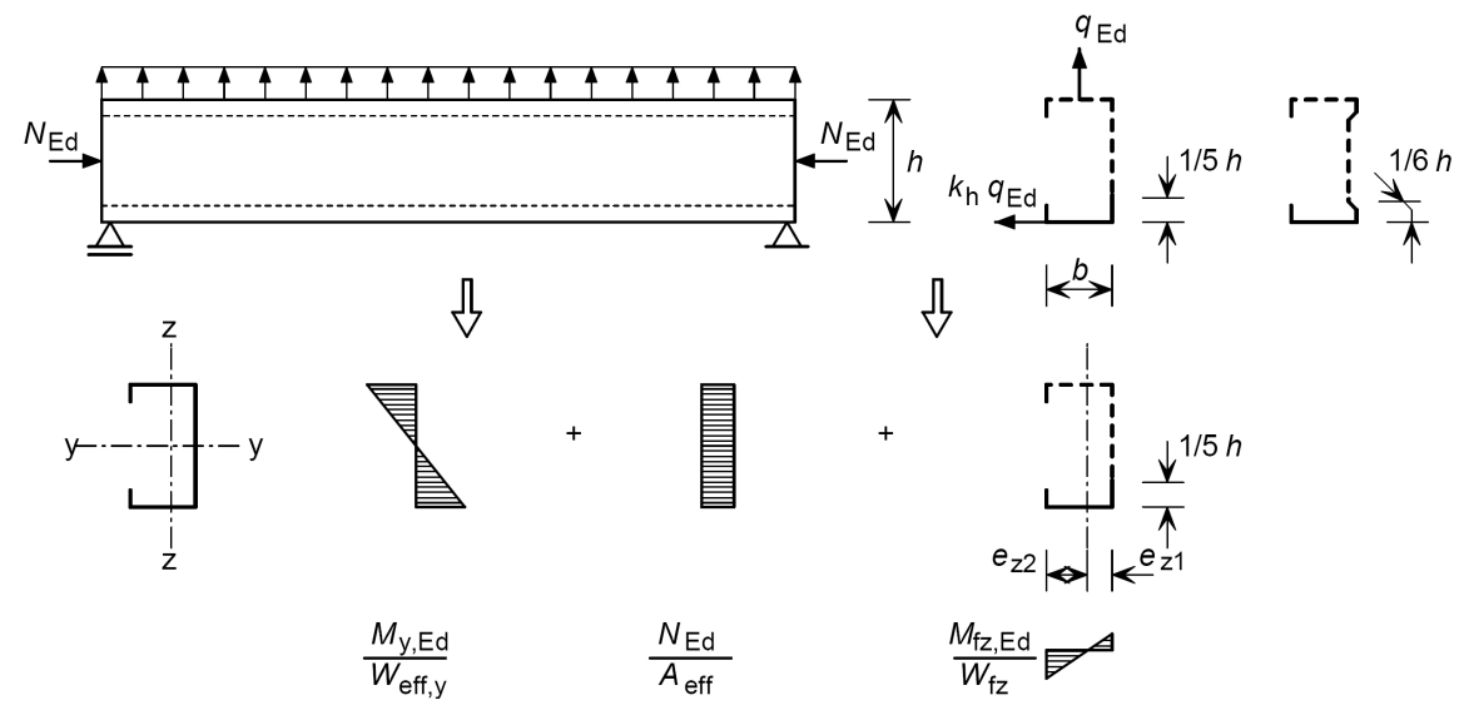

Slika 9 - Superpozicija učinaka djelovanja

Slobodna pojasnica je kod odižućeg djelovanja tlačno naprezana te je stoga potrebno provjeriti njezinu stabilnost prema izrazu:

$$
\frac{1}{\gamma_{\mathrm{LII}}}\left(\frac{M_{\mathrm{yEd}}}{W_{\mathrm{eff} \mathrm{y}}}\right)+\frac{M_{\mathrm{fz}, \mathrm{Ed}}}{W_{\mathrm{fz}}} \leq \frac{f_{\mathrm{y}}}{\gamma_{\mathrm{MI}}}
$$

gdje je $\chi_{u T}$ faktor redukcije za bočno torzijsko izvijanje (izvijanje savijanjem slobodne pojasnice).

\section{Primjer proračuna tankostijenog nosača prema Eurokodu}

\subsection{Nosač bez ukrućenja i bez pridržanja}

Na slici 10 prikazan je poprečni presjek tankostijenog nosača ( $C$ profil) koji nema nikakva ukrućenja na hrptu i pojasnici. Raspon obostrano slobodno oslonjenog nosača je 6 metara. Kvaliteta čelika nosača je S275.
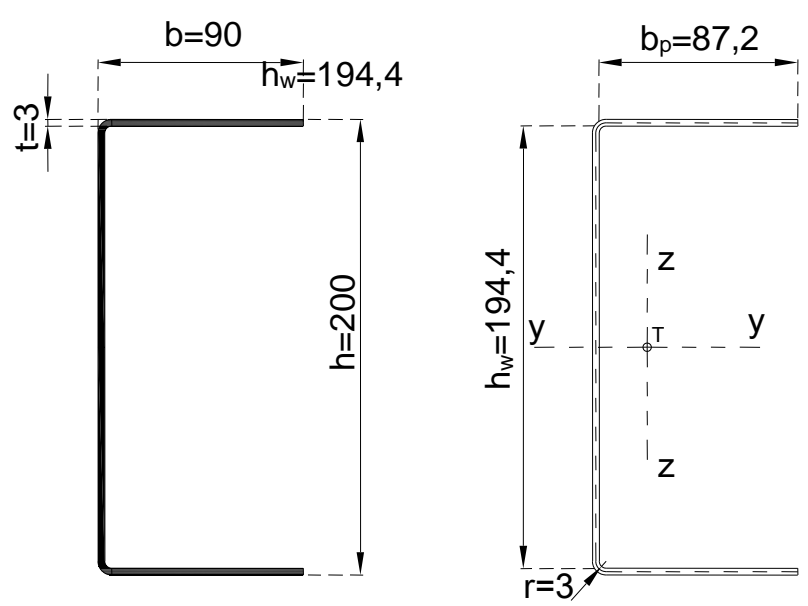

Slika 10 - Vanjske i fiktivne dimenzije elemenata poprečnog presjeka 
Budući da su zadovoljeni kriteriji iz tablice 1: $b / t=17<50 \mathrm{i} h / t=66<500 \sin \phi=500$, mogu se primijeniti odredbe za proračun prema EN 1993-1-3. Nadalje, budući da unutarnji polumjer zadovoljava granične uvjete $\mathrm{r}=3<5 \cdot \mathrm{t}=15 \mathrm{i} \mathrm{r}=3<0,10 \cdot \mathrm{b}_{\mathrm{p}}=5$, utjecaj zaobljenja uglova može se zanemariti kod proračuna otpornosti poprečnog presjeka, odnosno za poprečni presjek smije se usvojiti da je sastavljen od ravninskih elemenata s oštrim uglovima. Geometrijska svojstva bruto poprečnog presjeka (slika 10) prikazana su u tablici 3.

\section{Tablica 3 - Geometrijska svojstva bruto poprečnog presjeka}

\begin{tabular}{|c|c|c|l|}
\hline$A$ & Površina poprečnog presjeka & 1110 & $\mathrm{~mm}^{2}$ \\
\hline$I_{y}$ & Moment tromosti oko osi $y$ & 6945752 & $\mathrm{~mm}^{4}$ \\
\hline$I_{z}$ & Moment tromosti oko osi $z$ & 889162 & $\mathrm{~mm}^{4}$ \\
\hline$W_{y}$ & Elastični moment otpora oko osi $y$ & 69457 & $\mathrm{~mm}^{\mathrm{z}}$ \\
\hline$W_{z}$ & Elastični moment otpora oko osi $z$ & 13207 & $\mathrm{~mm}^{\mathrm{z}}$ \\
\hline
\end{tabular}

Djelotvorni poprečni presjek za savijanje (slika 11) odredit će se prema točki 2.1.4., a geometrijska svojstva djelotvornog poprečnog presjeka prikazana su u tablici 4.

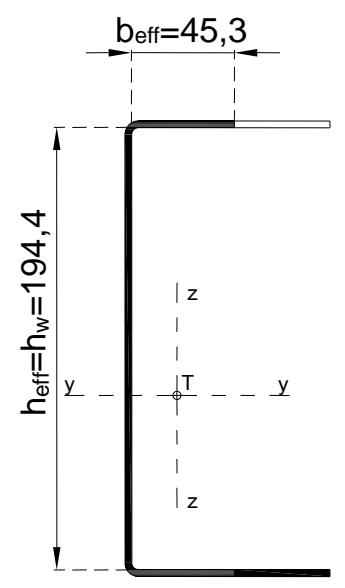

Tablica 4 - Geometrijska svojstva djelotvornog poprečnog presjeka za savijanje

\begin{tabular}{|c|c|c|l|}
\hline$A_{\text {eff }}$ & Površina poprečnog presjeka & 984 & $\mathrm{~mm}^{2}$ \\
\hline$I_{\mathrm{y}, \text { eff }}$ & Moment tromosti oko osi $y$ & 5570995 & $\mathrm{~mm}^{4}$ \\
\hline$I_{z, \text { eff }}$ & Moment tromosti oko osi $z$ & 565940 & $\mathrm{~mm}^{4}$ \\
\hline$W_{\mathrm{y} \text {,eff }}$ & Elastični moment otpora oko osi $y$ & 49476 & $\mathrm{~mm}^{\mathrm{a}}$ \\
\hline$W_{z, \text { eff }}$ & Elastični moment otpora oko osi $z$ & 7726 & $\mathrm{~mm}^{\mathrm{a}}$ \\
\hline
\end{tabular}

Slika 11 - Djelotvorni poprečni presjek za savijanje (tlak gore)

$\mathrm{Na}$ temelju dobivenih geometrijskih svojstava djelotvornog poprečnog presjeka za savijanje, možemo izračunati otpornosti tankostijenog nosača bez ukrućenja i pridržanja, tablica 5.

\section{Tablica 5 - Otpornosti tankostijenog nosača bez ukrućenja i bez pridržanja}

\begin{tabular}{|c|c|c|c|}
\hline \multicolumn{3}{|c|}{ Otpornost poprečnog presjeka } & Otpornost elementa \\
\hline & $\Lambda_{c, y, R d}[\mathrm{kNm}]$ & $V_{b, R d}[k N]$ & $M_{b, y, R d}[k N m]$ \\
\hline & 13,6 & 93,0 & 2,7 \\
\hline $\begin{array}{l}M_{c, y, R d} \\
V_{b, R d}\end{array}$ & \multicolumn{2}{|c|}{$\begin{array}{l}\text { na moment savijanja oko jače osi } \\
\text { na poprečnu silu }\end{array}$} & $\begin{array}{l}N_{b, R d} \quad \text { na izvijanje savijanjem } \\
M_{c, y, R d} \text { na bočno torzijsko izvijanje } \\
\text { razmak između točaka bočnog torzijskog } \\
\text { pridržanja je } 6 \mathrm{~m}\end{array}$ \\
\hline
\end{tabular}

\subsection{Nosač s ukrućenjima i bez pridržanja}

Tankostijeni nosač sa slike 10 profiliranjem je oblikovan u nosač na slici 12. Ukrućenje na hrptu je dodano zbog mogućnosti prijenosa uzdužne tlačne sile. Otpornost nosača na uzdužnu tlačnu silu nije razmatrana u ovome 
radu, budući da je analizirani nosač (podrožnica) dominantno naprezan na savijanje, ali i zbog opširnosti samoga rada.
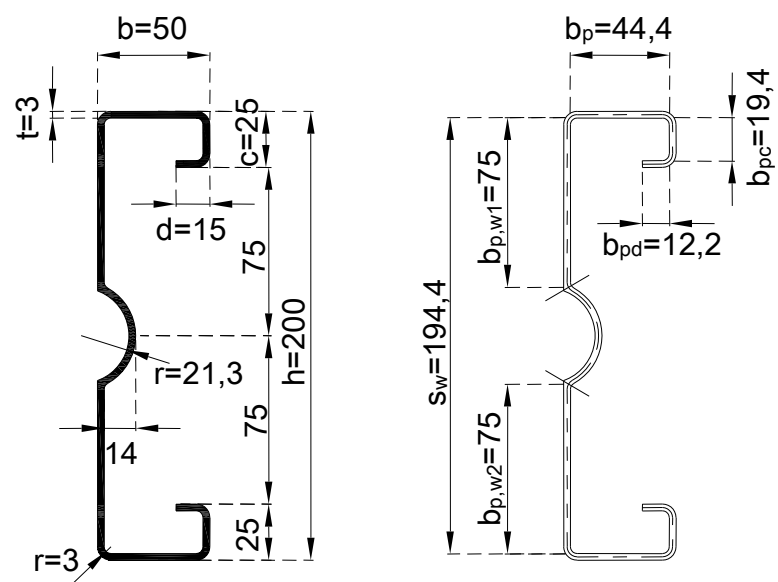
$b, h, c, d$ - ukupne vanjske dimenzije elemenata
$t$ - debljina stijenke profila
$r$ - unutarnji polumjer previjanja
$b_{p}$ - fiktivna ravna širina ravninskih elemenata
$s_{w}-$ visina hrpta između srednjih točaka uglova

\section{Slika 12 - Poprečni presjek tankostijenog nosača s ukrućenjima}

Budući da su zadovoljeni uvjeti iz tablice 1; $b / t=17<90, d / t=8<60, d / t=5<50$ i $h / t=66<500$, mogu se primijeniti odredbe za proračun prema EN 1993-1-3. Kako bi se osigurala dovoljna krutost i spriječilo primarno izvijanje samog ukrućenja, provjereni su geometrijski odnosi ukrućenja koji se nalaze unutar dozvoljenih granica: $0,2<c / b=0,5<0,6$ i $0,1<d / b=0,3 \leq 0,3$.

Početni djelotvorni poprečni presjek određen je preko koncepta djelotvorne širine, te je ustanovljeno da je djelotvoran cijeli poprečni presjek. Karakteristike poprečnog presjeka tankostijenog nosača s ukrućenjima, tablica 6:

\section{Tablica 6 - Geometrijska svojstva djelotvornog poprečnog presjeka nosača s ukrućenjima}

\begin{tabular}{|c|c|c|c|}
\hline$A$ & Površina poprečnog presjeka & 1086 & $\mathrm{~mm}^{2}$ \\
\hline$I_{y}$ & Moment tromosti oko osi $y$ & 5844302 & $\mathrm{~mm}^{4}$ \\
\hline$I_{z}$ & Moment tromosti oko osi $z$ & 346467 & $\mathrm{~mm}^{4}$ \\
\hline$W_{y}$ & Elastični moment otpora oko osi $y$ & 58442 & $\mathrm{~mm}^{2}$ \\
\hline$W_{z}$ & Elastični moment otpora oko osi $z$ & 10377 & $\mathrm{~mm}^{2}$ \\
\hline
\end{tabular}

Geometrijska svojstva rubnog ukrućenja na pojasnici (vidi sliku 3) su $A_{s}=165 \mathrm{~mm}^{2}, I_{s}=13964 \mathrm{~mm}^{4}$, dok su geometrijska svojstva međuukrućenja na hrptu (vidi sliku 4): $A_{s}=393 \mathrm{~mm}^{2}, l_{\mathrm{s}}=11006 \mathrm{~mm}^{4}$

Za rubno ukrućenje na pojasnici poprečnog presjeka, krutost opruge $K$, određena preko izraza (3) i (4), iznosi: $K=4,388 \mathrm{~N} / \mathrm{mm}$. Za međuukrućenje na hrptu poprečnog presjeka, krutost opruge $K$, određena preko izraza (3) i (5), iznosi: $K=3,330 \mathrm{~N} / \mathrm{mm}$. Elastični kritični napon izvijanja, izraz (6), iznosi $\sigma_{\mathrm{cr}, \mathrm{s}}=1375 \mathrm{~N} / \mathrm{mm}^{2}$ za rubno ukrućenje, odnosno $\sigma_{c r, s}=446 \mathrm{~N} / \mathrm{mm}^{2}$ za međuukrućenje. Rubno ukrućenje ima relativnu vitkost, izraz (10), $\bar{\lambda}_{d}=0,45$, dok međuukrućenje ima $\bar{\lambda}_{d}=0,78$. Zbog toga je faktor redukcije za rubno ukrućenje: $\chi_{d}=1$ $\left(\bar{\lambda}_{\mathrm{d}}<0,65\right)$, a za međuukrućenje $\chi_{\mathrm{d}}=1,47-0,723 \bar{\lambda}_{\mathrm{d}}=1,47-0,723 \cdot 0,78=0,91$.

$\mathrm{U}$ tablici 7 prikazane su otpornosti tankostijenog nosača $s$ ukrućenjima, te je prikazano koliko su se određene otpornosti promijenile u odnosu na nosač bez ukrućenja.

Tablica 7 - Otpornost tankostijenog nosača s ukrućenjima bez pridržanja

\begin{tabular}{|c|c|c|}
\hline \multicolumn{2}{|c|}{ Otpornost poprečnog presjeka } & Otpornost elementa \\
\hline$M_{c, y, R d}[\mathrm{kNm}]$ & $V_{b, R d}[\mathrm{kN}]$ & $M_{b, y, R d}[\mathrm{kNm}]$ \\
\hline 16,0 & 93,0 & 3,2 \\
\hline \multicolumn{3}{|c|}{ U odnosu na nosač bez ukrućenja i bez pridržanja } \\
\hline
\end{tabular}

Skejić, D; Ćosić, $R$

http://dx.doi.org/10.13167/2012.4.5 


\begin{tabular}{|l|l|r}
$+15 \%$ & $0 \%$ & $+15 \%$ \\
\hline
\end{tabular}

\subsection{Nosač s ukrućenjima i pridržanom gornjom pojasnicom}

Pretpostavlja se da je na nosač s ukrućenjima pričvršćen trapezni lim, slika 6 , debljine $0,75 \mathrm{~mm}$, dimenzija prikazanih na slici 13.

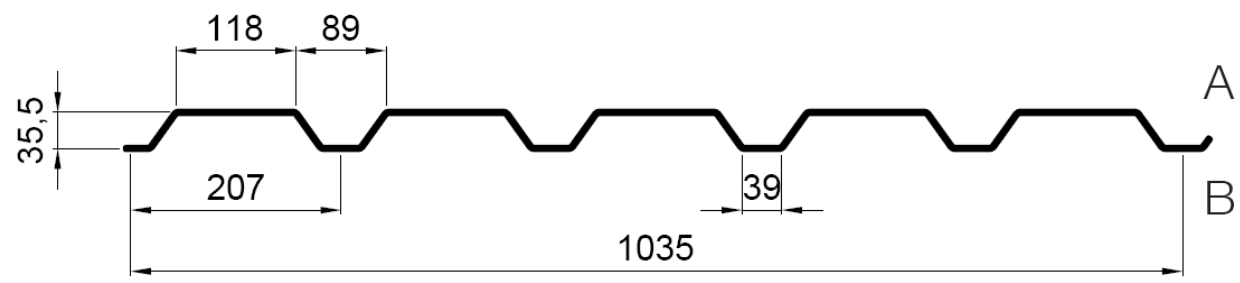

\section{Slika 13. Dimenzije trapeznog lima}

Norma daje uvjet koji je potrebno ispuniti da se podrožnica na spoju s trapeznim limom može smatrati bočno pridržanom u ravnini lima, izraz (13) i (14)

$$
\mathrm{S} \geq\left(\mathrm{EI}_{\mathrm{WW}} \frac{\Pi^{2}}{\mathrm{~L}^{2}}+\mathrm{GI}_{\mathrm{t}}+\mathrm{EI}_{\mathrm{Z}} \frac{\Pi^{2}}{\mathrm{~L}^{2}} 0,25 \mathrm{~h}^{2}\right) \frac{70}{\mathrm{~h}^{2}}
$$

Budući da je navedeni uvjet ispunjen, $6744 \mathrm{kN}>1141 \mathrm{kN}$, nosač se smatra bočno pridržanim u ravnini lima. Potrebno je provjeriti raspodjelu naprezanja za slobodnu pojasnicu koja se nalazi u tlaku, tj. za nosač opterećen odižućim djelovanjem. Koeficijent $k_{\widehat{h}_{\mathrm{R}}}$ određuje se prema EN 1993-1-3 (točka 10.1.4.1(4), slika 10.3), u kojoj je prikazano pretvaranje torzijskog i bočnog savijanja u ekvivalentno bočno opterećenje $k_{\bar{b}}$ " $q_{E d}$. Budući da je $\mathbb{k}_{\mathrm{h}}=-0,259$, i $b_{\mathrm{gmod}}=a=20 \mathrm{~mm}$ ekvivalentno bočno opterećenje, izraz (17) je $\mathrm{q}_{\mathrm{h}} \mathrm{Ed}=\mathrm{k}_{\mathrm{h}} \cdot \mathrm{q}_{\mathrm{Ed}}=0,259 \cdot \mathrm{q}_{\mathrm{Ed}}$.

Krutost zamjenske opruge (vidi sliku 7), izraz (16), iznosi $K=0,013 \mathrm{~N} / \mathrm{mm}$. Geometrijska svojstva nosača na elastičnoj podlozi, slika 16:

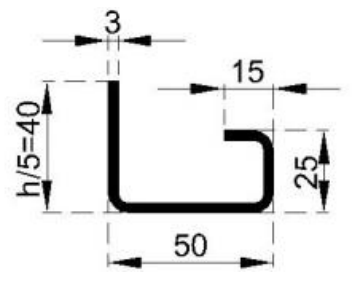

$$
\begin{aligned}
& I_{\mathrm{f} z}=126911 \mathrm{~mm}^{4} \\
& W_{\mathrm{fz}}=\frac{I_{\mathrm{f} z}}{\mathrm{Y}_{\mathrm{I}}}=\frac{126911}{23,2}=5470 \mathrm{~mm}^{\mathrm{a}}
\end{aligned}
$$

\section{Slika 16 - Slobodna pojasnica i $1 / 5$ hrpta}

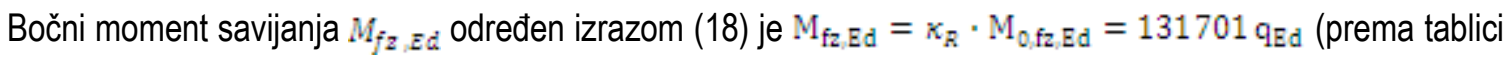
2: $\left.M_{0, t z, E d}=1165500 q_{E d}, K_{R}=0,113\right)$.

Za gravitacijsko opterećenje naprezanje je uzrokovano samo savijanjem u ravnini, te je otpornost nosača ista kao i kad je nepridržan. Kod odižućeg djelovanja mjerodavno naprezanje je u donjoj pojasnici, a uz savijanje u ravnini, uzrokovano je i bočnim i torzijskim savijanjem. Stoga je za provjeru pridržanog nosača u gornjoj pojasnici mjerodavno odižuće djelovanje. Maksimalno naprezanje (tlačno) pojavljuje se na spoju hrpta i pojasnice: 


$$
\begin{aligned}
& \sigma_{\text {max }} \text { Ed }<\frac{\mathrm{f}_{y}}{V_{\text {Mo }}} \\
& \frac{\mathrm{M}_{\mathrm{yEd}}}{\mathrm{W}_{\mathrm{eff} \mathrm{y}}}+\frac{\mathrm{M}_{\mathrm{fz} \mathrm{Ed}}}{\mathrm{W}_{\mathrm{fzy}}}<\frac{\mathrm{f}_{\mathrm{y}}}{\mathrm{YMo}_{\mathrm{MO}}} \\
& \frac{4500000 \mathrm{qEd}_{\mathrm{E}}}{58442}+\frac{131701 \mathrm{qEd}}{5470}<275 \\
& \text { qed }<2,7 \mathrm{kN} / \mathrm{m}
\end{aligned}
$$

$$
\begin{gathered}
M_{\mathrm{YEd}}=\frac{\mathrm{qEd}^{2}}{8}=\frac{\mathrm{qEd}_{\mathrm{E}} 6000^{2}}{8}=4500000 \mathrm{qEd} \\
\mathrm{M}_{\mathrm{fz} E d}=131701 \mathrm{qEd}
\end{gathered}
$$

Uz pretpostavku da je $q_{\mathrm{Rd}}=q_{\mathrm{Ed} \max }=2,7 \frac{\mathrm{kN}}{\mathrm{m}}$, proizlazi da jeM $\mathrm{cgyd}_{\mathrm{Rd}}=\left(\mathrm{q}_{\mathrm{Rd}} \mathrm{L}^{2}\right) / 8=\left(2,7 \cdot 6^{2}\right) / 8=12 \mathrm{kNm}$.

Slobodna pojasnica je kod odižućeg djelovanja tlačno naprezana te je stoga potrebno provjeriti njezinu stabilnost:

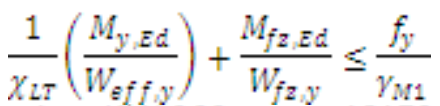

$$
\begin{aligned}
& \frac{1}{0,45}\left(\frac{4500000 \mathrm{q}_{\mathrm{Ed}}}{58442}\right)+\frac{131701 \mathrm{q} \mathrm{Ed}}{5470}<275
\end{aligned}
$$

Prema EN 1993-1-3, 10.1.4.2 određene su vrijednosti:$$
R_{0}=R=6,49
$$$$
\mathrm{l}_{\mathrm{fz}}=2,1 \mathrm{~m}
$$$$
\overline{\mathrm{X}}_{\mathrm{fz}}=1,26
$$$$
\chi_{\Perp T}=0,45 \text { (za krivulju izvijanja } b \text { ) }
$$

Uz pretpostavku da je $q_{\mathrm{Rd}}=q_{\mathrm{Ed} \text { max }}=1,4 \frac{\mathrm{KN}}{\mathrm{m}}$, proizlazi da jeM $\mathrm{M}_{\mathrm{b}, \mathrm{Rd}}=\left(q_{\mathrm{Rd}} \mathrm{L}^{2}\right) / 8=\left(1,4 \cdot 6^{2}\right) / 8=6,3 \mathrm{kNm}$.

\section{Tablica 8 - Otpornost tankostijenog nosača s ukrućenjima i pridržanom gornjom pojasnicom}

\begin{tabular}{|c|c|c|}
\hline \multicolumn{2}{|c|}{ Otpornost poprečnog presjeka } & Otpornost elementa \\
\hline$M_{c, y, R d}[\mathrm{kNm}]$ & $V_{b, R d}[\mathrm{kN}]$ & $M_{b, y, R d}[\mathrm{kNm}]$ \\
\hline 12 & 93 & 6,3 \\
\hline \multicolumn{3}{|c|}{ U odnosu na nosač s ukrućenjima i bez pridržanja } \\
\hline$-25 \%$ & $0 \%$ & $+49 \%$ \\
\hline \multicolumn{3}{|c|}{ U odnosu na nosač bez ukrućenja i bez pridržanja } \\
\hline$-12 \%$ & $0 \%$ & $+57 \%$ \\
\hline
\end{tabular}

Tablica daje vrlo zoran prikaz što se dogodi kada se gornja pojasnica pridrži trapeznim limom. To pridržanje izaziva dodatna naprezanja u slobodnoj tlačnoj pojasnici i time se, u odnosu na nosač bez pridržanja, smanji otpornost poprečnog presjeka na moment savijanja. Međutim, ovo pridržanje znatno doprinosi povećanju otpornosti na bočno torzijsko izvijanje.

\section{Zaključak}

Izvedbom ukrućenja, odnosno profilacijom poprečnog presjeka tankostijenog nosača, moguće je riješiti problem lokalnog instabiliteta, ali je pritom potrebno provjeriti i mogućnost distorzijskog izvijanja, tj. izvijanja samog ukrućenja. Učinci distorzijskog izvijanja mogu se odrediti provedbom linearnog ili nelinearnog proračuna izvijanja uporabom numeričkih metoda. Budući da numeričke metode nisu praktične za uobičajeno projektiranje, u europskoj normi EN 1993-1-3 dane su smjernice (proizašle iz teorijskih razmatranja i opsežnih laboratorijskih ispitivanja) kojima se na brz i jednostavan način mogu odrediti učinci distorzijskog izvijanja. Također je u normi dana pojednostavljena metoda kojom se može odrediti utjecaj pridržanja gornje pojasnice nosača pokrovnim limom. Pridržanje utječe na razdiobu normalnih naprezanja na cijelom poprečnom presjeku, a najveći se utjecaj javlja na nepridržanoj (donjoj) pojasnici, te se određivanje otpornosti nosača bazira na provjeri naprezanja na nepridržanoj pojasnici.

U prikazanom numeričkom primjeru prvo je analiziran nosač bez ukrućenja i bez pridržanja, tj. bez izvedenih profilacija i bez pridržanja gornje pojasnice pokrovnim limom. Na tom nosaču znatno je reducirana 
otpornost nosača zbog lokalnog instabiliteta poprečnog presjeka. Isti taj nosač oblikovan je u nosač s ukrućenjima, tj. previjene su mu pojasnice i izvedena je profilacija na hrptu. Dobivena je $15 \%$ veća otpornost nosača s ukrućenjima u odnosu na nosač bez ukrućenja. Dakle, bez dodatnog materijala ili razmatranja eventualnog pridržanja, samo učinkovitim oblikovanjem poprečnog presjeka, spriječen je lokalni instabilitet, odnosno povećana je otpornost nosača. Naposljetku, razmatran je nosač s ukrućenjima i pridržanom gornjom pojasnicom pokrovnim limom. Analizom je ustanovljeno značajno povećanje (49\%) otpornosti u odnosu na nosač s ukrućenjima, ali bez pridržanja. Zanimljivo je primijetiti da je to povećanje na razini elementa, dok je otpornost poprečnog presjeka smanjena za $25 \%$ zbog dodatnih naprezanja u nepridržanoj pojasnici.

U ovome radu su kroz numerički primjer suvremenog projektiranja tankostijenih nosača kvantificirane prednosti koje nudi profilacija i pridržanje limom. Međutim, bez obzira što pridržanje pokrovom može značajno povećati otpornost tankostijenog nosača, u praksi se ono često nepotrebno zanemaruje.

Proizvodni procesi i čelici razvili su se do te mjere da danas skoro ne postoje ograničenja u oblikovanju čeličnih limova, tj. tankostijenih profila. Njihova primjena omogućena je razvojem suvremenih normi za projektiranje tankostijenih nosača koje su bazirane na probabilističkim analizama velikog broja laboratorijskih ispitivanja. Bez obzira na to, postupci i smjernice navedeni u EN 1993-1-3 su jednostavni i prilagođeni zahtjevima svakodnevnog projektiranja. Koristeći europske norme, uz nešto više znanja, omogućeno je na praktičan i ekonomičan način projektiranje tankostijenih nosača.

\section{Literatura}

[1] European Committee for Standardization (CEN) 2006: EN 1993-1-3: Eurocode 3: Design of steel structures - Part 1-3: Supplementary rules for cold-formed members and sheeting

[2] Ćosić, R. 2011: Projekt čelične konstrukcije hale izvedene s tankostijenim profilima, diplomski rad, Sveučilište u Zagrebu, Građevinski fakultet, voditelj: Skejić, D.

[3] Šimić, D., Androić, B. 2003: Proračun tankostijenih trapeznih profila izloženih savijanju, Građevinar, Vol. 52, br. 12

[4] Outinen, J.; Perttola, D.; Hara, R.; Kupari, K.; Kaitila, O. 2000: Design of cold formed steel structures, Helsinki University of Technology Laboratory of Steel Structures Publications

[5] Section Builder; Creation of sections and calculation of their geometric properties, Version 1.7; User's guide

[6] STAAD.Pro 2007: Getting Started and Tutorials, Research Engineers, Bentley Solutions Centre

[7] European Committee for Standardization (CEN) 2006: EN 1993-1-5: Eurocode 3: Design of steel structures - Part 1-5: Plated structural elements

[8] Šimić, D. 2004: Proračun bočno pridržanih tankostijenih nosača otvorenog presjeka, Građevinar, Vol. 56, br. 5 